\title{
EQUILIBRIUM
}

Quarterly Journal of Economics and Economic Policy

2016 VOLUME 11 ISSUE 2, June

p-ISSN 1689-765X, e-ISSN 2353-3293

www.economic-policy.pl

Borowski, K.. (2016). Analysis of Monthly Rates of Return in April on the Example of Selected World Stock Exchange Indices. Equilibrium. Quarterly Journal of Economics and Economic Policy, 11(2), 307-325. DOI: http://dx.doi.org/10.12775/ EQUIL.2016.014

Krzysztof Borowski*

Warsaw School of Economics, Poland

\section{Analysis of Monthly Rates of Return in April on the Example of Selected World Stock Exchange Indices}

\section{JEL Classification: $G 11 ; G 14$}

Keywords: market efficiency; financial market seasonality; market anomalies; April effect

\begin{abstract}
The article presents a study of the effectiveness of 22 selected stock indices with the use of the rates of return in the month of April. The portfolio replicating the stock index was bought at the closing prices on the last session in March, and sold at the closing prices on the last session in April. The presence of market inefficiency is demonstrated in cases of the following indices: All-Ord, AMEX, BUX, CAC40, DAX, DJIA, DJTA, DJUA, EOE, FTSE100, SMI, SP500, but for the following indices: B-Share, Bovespa, Buenos, Hang-Seng, MEX-IPC, Nasdaq, Nikkei, Russel, TSE and WIG, the obtained monthly rates of return were statistically equal to zero. In the last part of the article, the correlation coefficients of rates of return for analyzed indices in month of April were surveyed.
\end{abstract}

(C) Copyright Institute of Economic Research

Date of submission: March 1, 2015; date of acceptance: September 28, 2015

*Contact: k.borowski@upcpoczta.pl, Warsaw School of Economics, al. Niepodległosci 162, 02-594 Warsaw, Poland 


\section{Introduction}

Efficient market hypothesis (EMH), the core of the influential paper of Fama, has been a cornerstone of financial economics for many decades (Fama, 1970, pp. 383-417). Although current definitions differ from that developed by Fama, the efficiency of markets prevents systematic outperforming the market, usually in a form of above-average risk-adjusted returns. The problem of the financial markets efficiency, especially of equity markets, has been discussed in a number of academic papers, which has led to a sizable set of publications examining this issue. Therefore, only some views presented in some of the scientific papers, regarding market efficiency, have been included in this paper. In many empirical works dedicated to the time series analysis of rates of return and stock prices, there were found statistically significant effects of both types, i.e. calendar effects and effects associated with the size of companies. These effects are called "anomalies", because their existence testifies against market efficiency (Simson, 1988, pp. 124-156; Jajuga \& Jajuga, 2006, pp. 147-149).

One of the most common calendar anomalies observed on the financial markets are (Nowakowski \& Borowski, 2005, pp. 322-329) ${ }^{1}$ :

- Day-of-the-week effect - daily average rates of return registered on the stock market differ for various days of the week. One of the first works dedicated to this type of effect was developed by Hirsh (Hirsh, 1987, pp. 98-124). He examined the behavior of the S\&P 500 index in the period from June 1952 to June 1985, proving that the index close on Monday was lower in 57\% than the index close on the preceding Friday. For other days of the week, the following trend was observed - the index close on one session was higher than the index close on the previous session (Tuesdays/Monday of in $43 \%$ observations, Wednesday/Tuesday in $55,6 \%$, Thursday/Wednesday in 52,6\%, Friday/Thursday in 58\%). The day-of-the-week effect was presented on the US market (Jaffie et al., 1989, pp. 641-650; French, 1980, pp. 55-69; Lakonishok \& Maberly, 1990, pp. 231-243 ), as well as on other markets (Kato et al., 1990; French, 1980, pp. 55-69; Lakonishok \& Maberly, 1990, pp. 231-243; Connolly, 1989, pp. 133-169).

- Monthly effect - achieving by portfolio replicating the specified stock index, different returns in each month. For the first time, this effect was observed by Keim (1983, pp. 13-32), who noted that the average rate of return on stocks with small capitalization is the highest in January.

${ }^{1}$ A broad review of the literature regarding the financial markets efficiency can be found in the research by Nowakowski and Borowski (Nowakowski \& Borowski, 2005, pp. 322-329). 
Rozeff and Kinelly, applying equally-weighted equity index, found that for the period 1904-1974 in the US market, the average return per month was about $0.5 \%$, whereas for January it was $3.5 \%$ (Rozeff \& Kinelly, 1976, pp. 379-402). But Lakonishok and Smid, using a sample for the period of 1987-1986 for the Dow Jones Industrial Average (DJIA), found no January effect (Lakonishok \& Smith, 1988, pp. 403-425). Bernstein, taking into consideration the behavior of the US equity market in the period from 1940 to 1989, discovered the interdependence between rates of returns in each of analyzed months (Bernstein, 1991, pp. 25-45). Modern bodies of research, e.g. Gu and Schwert, proved that in the last two decades of the twentieth century, the phenomenon of the month-of-the-year effect was much weaker (Gu, 2003, pp. 18-28), (Schwert, 2002, pp. 937-972). This fact would suggest that the discovery and dissemination of the monthly effect in world financial literature contributed to the increase of market efficiency.

- Other seasonal effects - for example: the "within-the-month effect" - positive rates of returns only occur in the first half of the month (Ariel, 1987, pp. 161-174; Kim \& Park, 1994, pp.145-157) or the holiday effect - tendency to price increase before trading breaks caused by holidays (Ariel, 1987, pp. 161-174; Ariel, 1990, pp. 1611-1626).

Among the monthly effects, the ones that can be distinguished are the January effect and St. Nicholas rally (also called "the end of the year effect"). The most popular monthly effect is called "January effect", i.e. the tendency to observe higher average returns of the stock market indices in the first month of the year. In turn, the effect described in the scientific literature as "St. Nicholas rally" - the second half of December- is characterized by the highest rates of return of the 24 half-months. Both of these effects were analyzed in a number of papers (Choudhry, 2001, pp. 1-11; Fountas \& Konstantinos, 2002, pp. 291-299). In turn, in the scientific literature, the tendency to register highly positive rates of return on the stock market in April is called "April effect". This effect was particularly strong on the British equity market (Rozeff \& Kinney, 1976, pp. 379-402; Corhay et al., 1988). Gultekin and Gultekin, analyzing the data for 1959-1979, proved strong seasonal pattern in returns on the British market. Although January was the best single month, the period from December to April consisted of months which on average produced positive returns. The compound return calculated for the December-April period was higher than the compound return for the whole year, because other seven months generated a negative return (Gultekin \& Gultekin, 1983, pp. 469-481). According to Bernstein, the rates of return in the month of April are strongly positive (Bernstein, 1996, pp. 76-77). However, some authors have questioned the 
existence of this effect in selected markets - e.g. Raj and Thurston proved that both the January and April effect were not observed on the New Zealand Stock Exchange (Raj \& Thurston, 1994, pp. 81-83). Hasan and Raj, as well as Li and Liu, came to the same conclusion (Hasan \& Raj, 2001, pp. 100-105; Li \& Liu, 2010, pp. 9-14). On the other hand, Raj and Kumari proved that on Bombay Stock Exchange and National Stock Exchange in India, the January effect was not observed, but the rates of return in April were significantly higher than in other nine months of the year. In their opinion, the main factor responsible for the occurrence of the April effect was the strong equity sale on the stock exchange in March due to the end of tax year in India, which falls in March (Raj \& Kumari, 2006, pp. 235-246). A similar explanation for the existence of the April effect on other stock exchanges is provided by, among others, Reinganum and Shapiro (Reinganum \& Shapiro, 1987, pp. 281-295), and on the New Zealand Stock Exchange - Hasan and Raj (Hasan \& Raj, 2001, pp. 100-105). According to the authors, the introduction of income tax on capital gains in April 1965 in the UK and the change of the fiscal year beginning from January 1 to April 1, was the main incentive responsible for the April effect on the British equity market. The occurrence of the April effect on the UK market has also been proven in other papers (Clare et al., 1995, pp. 398409).

In Poland, research on market efficiency and the occurrence of seasonal effects were conducted by several authors (Buczek, 2005, pp. 51-55; Szyszka, 2007, pp. 141-146; Czekaj et al., 2001, pp. 85-96). A study done by these authors indicate a high level of efficiency in the weak form of the Polish equity market. It can be stated that, apart from the initial period (until 1994), the prices of shares listed on the Warsaw Stock Exchange satisfy the assumptions of the weak form of market efficiency. Buczek confirmed the existence of anomalies associated with the occurrence of the January effect (Buczek, 2005, pp. 51-55). The author proved that in the period of 1999-2004, the average rate of return of WIG index in January was equal to $6.2 \%$, while the average rate of return calculated for all other months stayed at the level of $0.8 \%$

The aim of this paper is to examine the prevalence of the April effect with the use of close price during last session in March and April on the selected financial markets represented by the following indices: All-Ord, AMEX, B-Shares, Buenos, BUX, CAC40, DAX, DJIA, DJTA, DJUA, EOE, FTSE100, Hang Seng, Middle-IPC, Nasdaq, Nikkei, Russel, SMI, S\&P500, TSE. 


\section{Research Methodology}

Analyzing the occurrence of the effects of seasonality, the calculation of rates of return with the use of close prices for two consecutive sessions is implemented (Gultekin \& Gultekin, 1983, pp. 469-481).

In the case of the monthly effects, the rate of return will be calculated basing on the close value of the analyzed stock index on the last session in March $\left(I_{t-1}\right)$ in relation to the close value of the index on the last session in April $\left(I_{t}\right)$ :

$$
r=\frac{I_{t}-I_{t-1}}{I_{t-1}}
$$

Due to the fact that the analyzed indices have different starting dates of their publication, and taking into account the contents of the database provided by Bank Ochrony Srodowiska Brokerage House, the analysis of the seasonality effects for individual indices will be proceeded in different time intervals.

For each analyzed index available in the database provided by BOS Brokerage House, the monthly rate of return in April will be calculated. Then the null hypothesis will be tested that may be formulated as follows: the average monthly rate of return in April for each of the 22 analyzed index is equal to zero (for $\alpha=5 \%$ ). Rejection of the null hypothesis would allow to accept the alternative hypothesis that the average monthly rate of return in the month of April, for a particular stock index, is statistically different from zero. This fact will prove the occurrence of the April effect on the basis of closing prices on the last sessions in March and April, for a given index.

The occurrence of April effect with the use of the closing price on the last sessions in March and April, permits to achieve excess returns in long term (which can be used in practice) in case of the analyzed stock index, and is a proof of the existence of the calendar anomalies, providing against the theory of the efficiency of financial markets, what testifies against the theory of market efficiency. The outcome may be regarded as a part of the ongoing discussions on the hypothesis of financial markets efficiency, which was introduced by Fama (Fama, 1970, pp. 383-417).

For the research, the following 22 indices were selected:

1. All-Ordinaries - the index of the Stock Exchange in Sydney,

2. AMEX - the American Stock Exchange index,

3. B-shares - the stock market index in Shanghai, 
4. Bovespa - the index of the stock exchange in Sao Paulo,

5. Bueons - the stock market index in Bueons Aires,

6. BUX - the index of the Budapest Stock Exchange,

7. CAC 40 - the index of the stock exchange in Paris,

8. DAX - The Frankfurt Stock Exchange index,

9. DJIA - Dow Jones Industrial Average - the index of the stock exchange in New York, composed of industrial sector companies,

10.DJTA - Dow Jones Transportation Average - the index of the stock exchange in New York, composed of transport sector companies,

11.DJUA - Dow Jones Utility Average - the index of the stock exchange in New York, composed of utility sector companies,

12.EOE - the index of the stock exchange in Amsterdam,

13.FTSE 100 - the index of the London Stock Exchange,

14.Hang Seng - the index of the Stock Exchange in Hong Kong,

15.MEX-IPC - the index of the Stock Exchange in Mexico,

16. Nasdaq - the stock market index in the US,

17.Nikkei - the index of the Tokyo Stock Exchange,

18. Russel - the stock market index in the US,

19.SMI - the index of the stock exchange in Zurich, Switzerland,

20.S\&P 500 - the index of the stock exchange in New York,

21.TSE 300 - the index of the stock exchange in Toronto,

22.WIG - the index of the Warsaw Stock Exchange.

The analyzed group of equity indices consists of two group of indices:

a) Equity indices of developed countries (e.g. DJIA, TSE 300, S\&P 500),

b) Equity indices of emerging markets (e.g. WIG, BUX, MEX-IPC, Bovespa, Buenos).

The choice of indices is followed by the availability of data for multiple time intervals offered by Bank Ochrony Srodowiska Brokerage House. In turn, the index abbreviations are in accordance with generally accepted abbreviations applied in the information services.

The starting dates, concerning the availability of the value of the analyzed indexes, are presented in Table 1. Regarding CAC40 index, the covered period when the seasonality effect was examined, extends from April 1995 to April 2014, which is equivalent to 20 monthly rates of return. The longest available time series covering more than 40 years, enabled the calculation of 43 April monthly rates for Nasdaq index, and 45 monthly rates of return for the following indices: S\&P500, Nikkei, DJIA. The transaction cost were not included in the analysis. 
Table 1. The starting date and the number of monthly returns for each index

\begin{tabular}{|c|c|c|}
\hline Index & $\begin{array}{c}\text { The first return in included } \\
\text { in the analysis }\end{array}$ & $\begin{array}{c}\text { The number of returns } \\
\text { in the analysis }\end{array}$ \\
\hline All-Ord & 30.04 .1990 & 25 \\
\hline AMEX & 28.04 .1995 & 20 \\
\hline B-Shares & 30.04 .1999 & 16 \\
\hline Bovespa & 28.04 .1995 & 20 \\
\hline Buenos & 30.04 .1997 & 18 \\
\hline BUX & 28.04 .1995 & 20 \\
\hline CAC40 & 28.04 .1995 & 20 \\
\hline DAX & 28.04 .1995 & 20 \\
\hline DJIA & 30.04 .1970 & 45 \\
\hline DJTI & 28.04 .1995 & 20 \\
\hline DJUA & 28.04 .1995 & 20 \\
\hline EOE & 28.04 .1995 & 20 \\
\hline FTSE100 & 30.04 .1993 & 22 \\
\hline Hang Seng & 29.04 .1988 & 27 \\
\hline MEX-IPC & 29.04 .1994 & 21 \\
\hline Nasdaq & 28.04 .1972 & 43 \\
\hline Nikkei & 30.04 .1970 & 45 \\
\hline Russel & 30.04 .2002 & 13 \\
\hline SMI & 28.04 .1995 & 20 \\
\hline SP500 & 30.04 .1970 & 45 \\
\hline TSE & 30.04 .1990 & 25 \\
\hline $\mathrm{WIG}^{*}$ & 30.04 .1992 & 23 \\
\hline
\end{tabular}

Due to the fact that the first session on the Warsaw Stock Exchange was held on 04.16.1991, the first April monthly return for WIG index was calculated in 1992. Given the fact that at that time, sessions on the Warsaw Stock Exchange were conducted only once in a week, as well as that only rates of return in the second half of April 1991 would be taken into account, it appears to be unjustified to calculate monthly return in April 1991.

Source: own calculation.

In the last part of the investigation, the correlation matrix between the April returns for different stock market indices was calculated, what will allow to assess the degree of interdependence between the different markets represented by equity indices.

\section{Analysis of Results}

The results for analyzed stock indices are summarized in Table 2 and Table 3 . In the cases where the number of monthly rates of return was lower than 30, the t-Student distribution was applied. Otherwise, the normal distribution was implemented. 
The nominal rate of return in the Table 2 and Table 3 was calculated as the multiplication of the average monthly return in the month of April by the factor equal to 12. If there were no reasons to reject the null hypothesis, then in the Table 2 and Table 3, in the line entitled "Null hypothesis verification" the word "Truth" is used, but when the null hypothesis was rejected in favor of the alternative hypothesis - the word "False" was implemented.

The average April returns were statistically different from zero in 12 out of the 22 analyzed indices, i.e. in 54,54\% of analyzed cases. The April returns, statistically different from zero were observed for the following indices: All-Ord, AMEX, BUX, CAC40, DAX, DJIA, DJTA, DJUA, EOE, FTSE100, SMI, SP500. For all remaining indices, e.g. B-Share, Bovespa, Buenos, Hang-Seng, MEX-IPC, Nasdaq, Nikkei, Russel, TSE and WIG, there were no reasons to reject the null hypothesis, which means that the average rate of return was equal to 0 with the confidence level of $95 \%$. It is worth considering that the group of indices, for which the April average rates of return were statistically different form zero, is dominated by the equity indexes of developed countries: ALL-Ord, AMEX, CAC40, DAX, DJIA, DJTA, DJUA, EOE, FTSE100, SMI, SP500. The Budapest Stock Exchange (BUX), as the only representative of the group of countries with lower levels of financial market development compared to USA or UK, was included in the group of indices for which the hull hypothesis was rejected.

The group of indices, for which average monthly return in April is equal zero (for $\alpha=5 \%$ ), is dominated by stock markets indices of countries with less significant level of financial market development (B-Share, Bovespa, Buenos, MEX-IPC and WIG), although the representation of the stock market indices of the countries with higher level of financial market development is large (Hang-Seng, Nikkei, Russel, TSE). This fact allows to draw the conclusion that the April effect was observed more frequently in the developed than in the developing (emerging markets) countries.

In all analyzed cases, the monthly average returns in April remained positive and reached the highest value equal to $4.20 \%$ for the BUX index, which was higher by $0.05 \%$ than the return calculated for the WIG index. But it should be noted that the null hypothesis was rejected in the case of the BUX index, and there were no reasons to reject the null hypothesis for WIG index. 


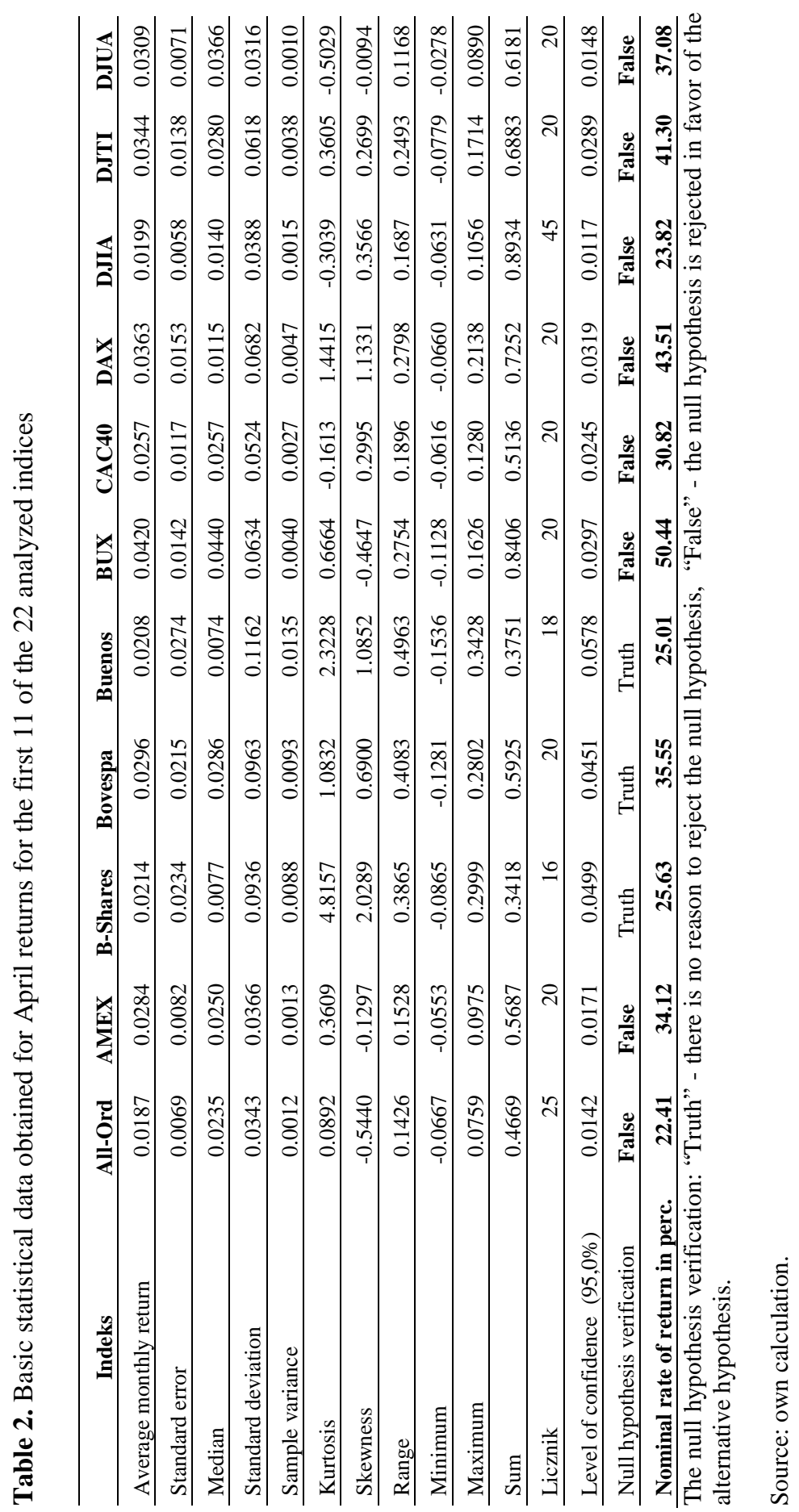




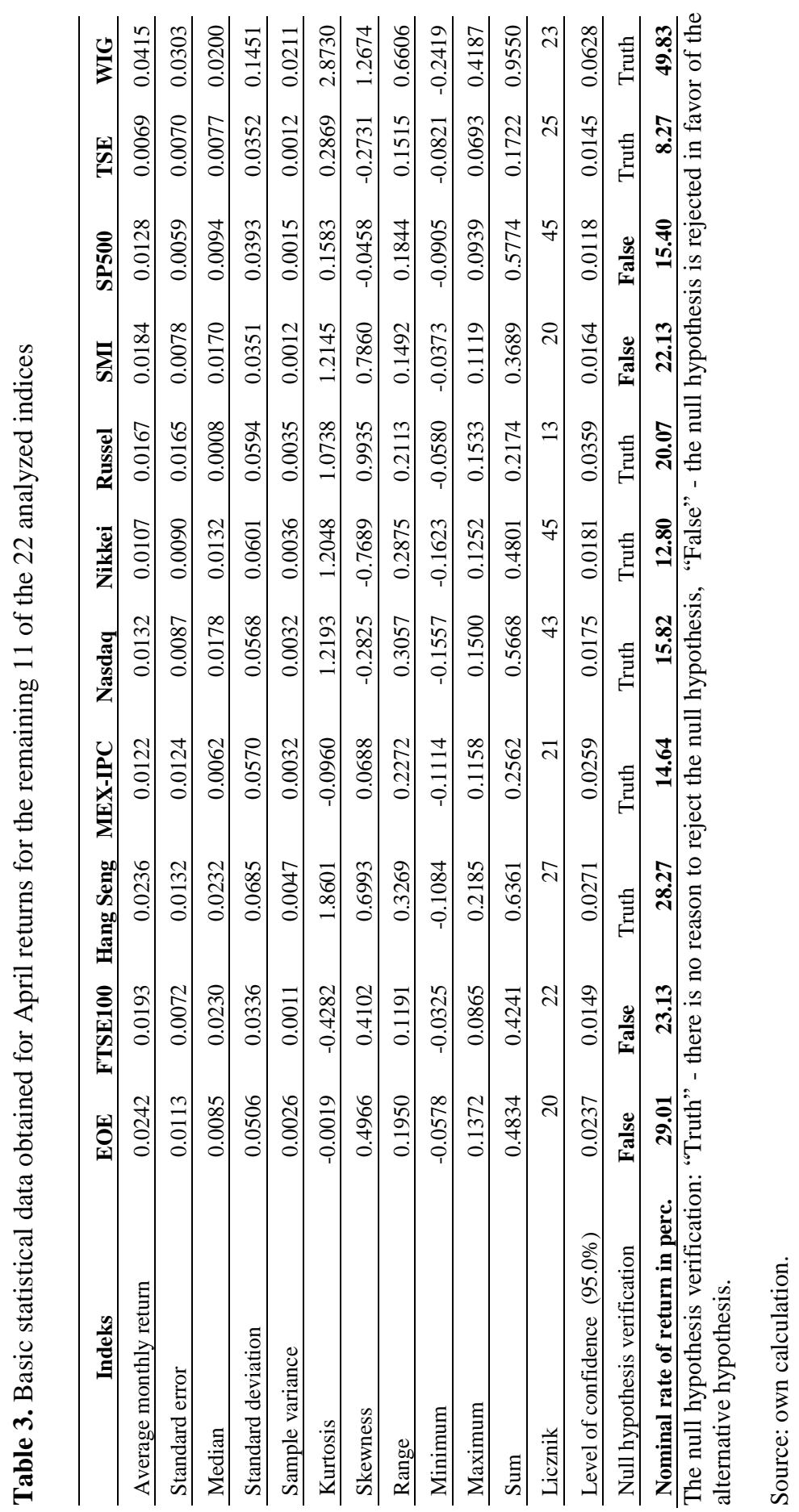


The lowest average monthly return in April, equal to 0.69\%, was registered for the Canadian index TSE (in this case there were no reasons to reject the null hypothesis).The biggest error in estimating the average return in April and equal to 3.03\% was observed for the WIG index, but the lowest was noted for MEX-IPC $(0.58 \%)$. The index volatility analysis in the month of April permits to draw the conclusion that the highest value of the standard deviation was calculated for the WIG index (14.51\%) and the lowest for DJUA (3.16\%). In the case of the range of trait variability, the highest value was obtained by the WIG index (0.6606), and the smallest by DJUA (0.1168).

The percentages of positive returns registered in the month of April, ordered by decreasing value, are presented in the Table 4. For AMEX and DJUA positive returns were observed in $80 \%$ of all cases, for BUX and DAX in 75\%, and for the following 4 indexes: CAC40, DJTA, EOE and SMI in $75 \%$. On the British market, positive returns were registered in $68.18 \%$ (FTSE100) and in Warsaw in 60.87\% (WIG). Regarding TSE index, positive returns in April were calculated in 52\% of analyzed cases. For the same index, the percentage of negative returns recorded in April mounted $48 \%$ and was the highest.

Table 4. The number and percentage of positive and negative returns in the month of April for the analyzed stock indices, sorted in descending order for the percentage of positive returns

\begin{tabular}{lcccccc}
\hline Index & $\begin{array}{c}\text { The number } \\
\text { of all } \\
\text { calculated } \\
\text { monthly } \\
\text { returns }\end{array}$ & $\begin{array}{c}\text { Number of } \\
\text { positive } \\
\text { returns }\end{array}$ & $\begin{array}{c}\text { Number of } \\
\text { negative } \\
\text { returns }\end{array}$ & $\begin{array}{c}\text { Percentage } \\
\text { of positive } \\
\text { returns }\end{array}$ & $\begin{array}{c}\text { Percentage } \\
\text { of negative } \\
\text { returns }\end{array}$ & $\begin{array}{c}\text { Sum of } \\
\text { percentage } \\
\text { of positive } \\
\text { and } \\
\text { negative } \\
\text { returns }\end{array}$ \\
\hline AMEX & 20 & 16 & 4 & $80.00 \%$ & $20.00 \%$ & $100 \%$ \\
\hline DJUA & 20 & 16 & 4 & $80.00 \%$ & $20.00 \%$ & $100 \%$ \\
\hline BUX & 20 & 15 & 5 & $75.00 \%$ & $25.00 \%$ & $100 \%$ \\
\hline DAX & 20 & 15 & 5 & $75.00 \%$ & $25.00 \%$ & $100 \%$ \\
\hline CAC40 & 20 & 14 & 6 & $70.00 \%$ & $30.00 \%$ & $100 \%$ \\
\hline DJTA & 20 & 14 & 6 & $70.00 \%$ & $30.00 \%$ & $100 \%$ \\
\hline EOE & 20 & 14 & 6 & $70.00 \%$ & $30.00 \%$ & $100 \%$ \\
\hline SMI & 20 & 14 & 6 & $70.00 \%$ & $30.00 \%$ & $100 \%$ \\
\hline FTSE100 & 22 & 15 & 7 & $68.18 \%$ & $31.82 \%$ & $100 \%$ \\
\hline All-Ord & 25 & 17 & 8 & $68.00 \%$ & $32.00 \%$ & $100 \%$ \\
\hline Hang Seng & 27 & 18 & 9 & $66.67 \%$ & $33.33 \%$ & $100 \%$ \\
\hline SP500 & 45 & 30 & 15 & $66.67 \%$ & $33.33 \%$ & $100 \%$ \\
\hline
\end{tabular}


Table 4 continued

\begin{tabular}{lcccccc}
\hline Index & $\begin{array}{c}\text { The number } \\
\text { of all } \\
\text { calculated } \\
\text { monthly } \\
\text { returns }\end{array}$ & $\begin{array}{c}\text { Number of } \\
\text { positive } \\
\text { returns }\end{array}$ & $\begin{array}{c}\text { Number of } \\
\text { negative } \\
\text { returns }\end{array}$ & $\begin{array}{c}\text { Percentage } \\
\text { of positive } \\
\text { returns }\end{array}$ & $\begin{array}{c}\text { Percentage } \\
\text { of negative } \\
\text { returns }\end{array}$ & $\begin{array}{c}\text { Sum of } \\
\text { percentage } \\
\text { of positive } \\
\text { and } \\
\text { negative } \\
\text { returns }\end{array}$ \\
\hline Nikkei & 45 & 29 & 16 & $64.44 \%$ & $35.56 \%$ & $100 \%$ \\
\hline Nasdaq & 43 & 27 & 16 & $62.79 \%$ & $37.21 \%$ & $100 \%$ \\
\hline DJIA & 45 & 28 & 17 & $62.22 \%$ & $37.78 \%$ & $100 \%$ \\
\hline WIG & 23 & 14 & 9 & $60.87 \%$ & $39.13 \%$ & $100 \%$ \\
\hline MEX-IPC & 21 & 12 & 9 & $57.14 \%$ & $42.86 \%$ & $100 \%$ \\
\hline B-Shares & 16 & 9 & 7 & $56.25 \%$ & $43.75 \%$ & $100 \%$ \\
\hline Buenos & 18 & 10 & 8 & $55.56 \%$ & $44.44 \%$ & $100 \%$ \\
\hline Bovespa & 20 & 11 & 9 & $55.00 \%$ & $45.00 \%$ & $100 \%$ \\
\hline Russel & 13 & 7 & 6 & $53.85 \%$ & $46.15 \%$ & $100 \%$ \\
\hline TSE & 25 & 13 & 12 & $52.00 \%$ & $48.00 \%$ & $100 \%$ \\
\hline
\end{tabular}

Source: own calculation.

Let's consider the following investment strategy (Portfolio Replicating Strategy in April). The long position in the investment portfolio, replicating the specific stock index, is opened on the last session in March at closing prices, and is canceled on the last session in April, also at closing prices. During all months in a year, the financial resources are invested on an interest-free deposit. The cumulative returns in the period of 1995-2014 (i.e. during 20 years), for each of the analyzed stock market indices are shown in Figure 1 (except for those, for which the number of monthly returns was lower than 20 years, i.e. for the following indexes: B-Shares, Buenos and Russel).

The highest rate of return available to achieve for this type of strategy was registered in the case of the WIG index and equal to $123 \%$. The second highest return amounted to $120 \%$ and was observed for the other stock exchange originating from the Central and Eastern Europe, e.g. for Hungarian exchange, represented by BUX index, The lowest rate of return, recorded for the Portfolio Replicating Strategy in April attained the level of 26\% and was calculated for TSE index - Figure 2. 
Figure 1. The cumulative returns in the investment horizon of 20 years (1995 -2014) for analyzed stock indices with the use of the Portfolio Replicating Strategy in April

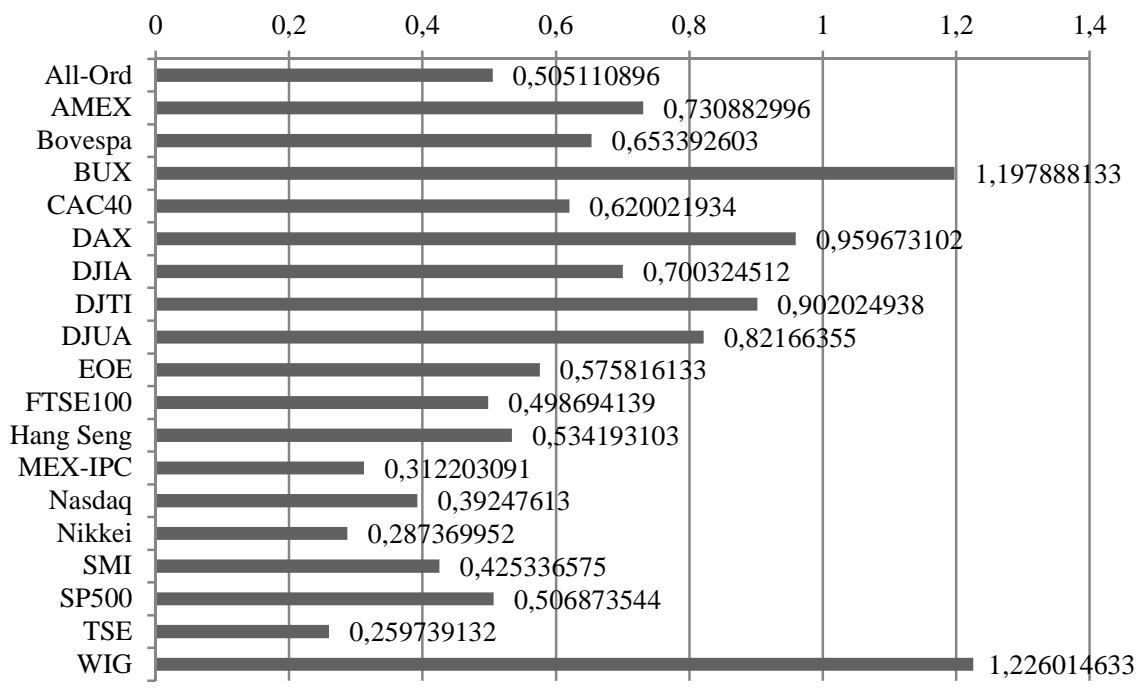

Source: own calculation.

Figure 2. The value of the unit portfolio for the following 3 indices: WIG, BUX and TSE in the period 1995-2014 with the use of Portfolio Replicating Strategy in April

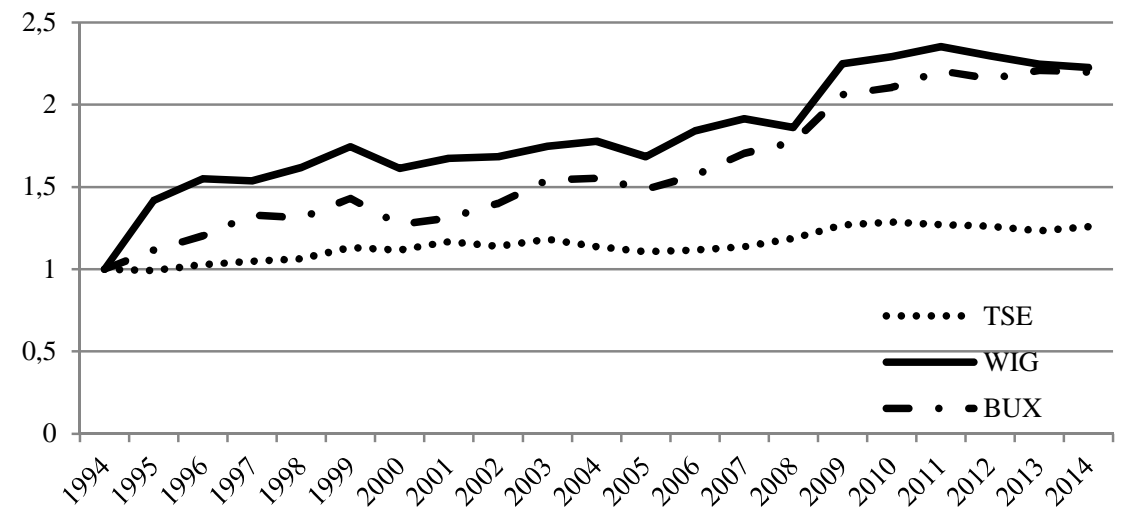

Source: own calculation. 


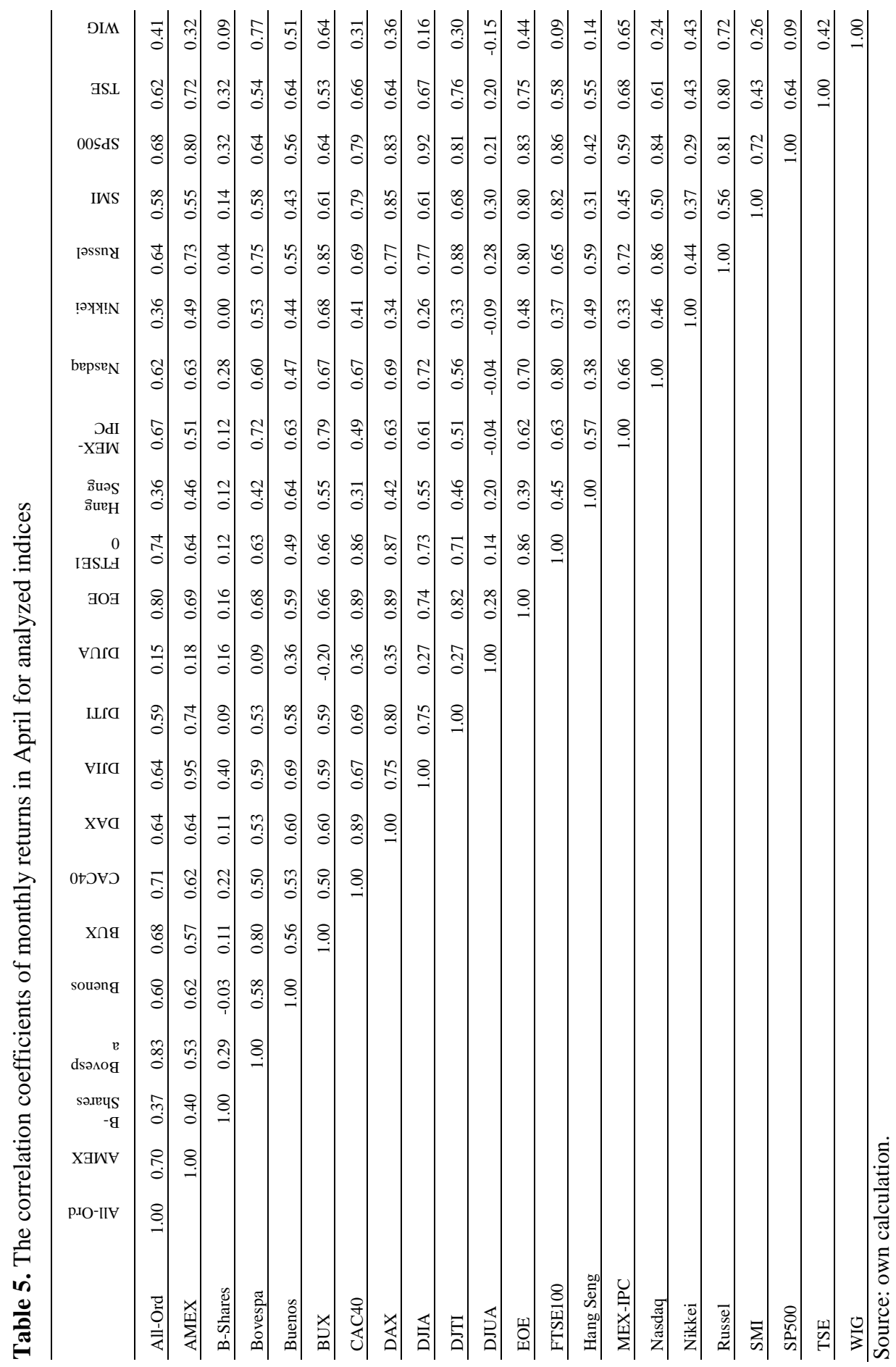


The correlation coefficients of April monthly returns for all analyzed indexes are given in Table. 5. The negative correlation coefficients were recorded only in 6 out of 231 cases. The most negative $(-0.20)$ was computed for two indices: BUX and DJUA, while for the pair of indices WIG and DJUA the factor mounted to -0.15 . In other cases, the correlation coefficient was higher than -0.10. It is worth noting that in 4 cases (DJUA, WIG MEX-IPC and Nikkei), the correlation coefficient was slightly negative. The most positive value of the correlation coefficient for April monthly returns was observed for two indices: AMEX and DJIA (0.95), and the second most positive for also two American stock indices: DJIA and S\&P500 (0.92). A total number of correlation coefficients greater than 0.6 was equal to 105 , that represents $45.45 \%$ of all calculated correlation coefficients - see Table. 6 .

For Polish investors, the practical significance may have a high correlation coefficient of April monthly returns, calculated for WIG index and the following indices of foreign stock exchanges: Bovespa (0.77), BUX (0.66), MEX-IPC (0.65) and Russel (0.72). In turn, the correlation coefficient observed for WIG and FTSE100, as well as for the pair of indices: WIG and S\&P500, was almost close to zero, and in both cases was equal to 0.09 .

The relatively high correlation coefficient, calculated in the analyzed period, for returns of the pair of indices: WIG and BUX (approx. 0.66), proves undoubtedly the cash inflow from foreign investment funds on the stock exchanges in Poland and Hungary. Stock exchanges in both countries belong to the segment of emerging markets, and many funds making portfolio investments, treats these two exchanges as a single investment area.

Table 6. The numbers and percentage of the correlation coefficients in different ranges

\begin{tabular}{ccc}
\hline $\begin{array}{c}\text { Correlation coefficient } \\
\text { greater than }\end{array}$ & $\begin{array}{c}\text { Number of correlation } \\
\text { coefficients }\end{array}$ & $\begin{array}{c}\text { Percentage of all } \\
\text { correlation coefficients }\end{array}$ \\
\hline 0,5 & 140 & $60.61 \%$ \\
\hline 0,6 & 105 & $45.45 \%$ \\
\hline 0,7 & 55 & $23.81 \%$ \\
\hline 0,8 & 26 & $11.26 \%$ \\
\hline 0,9 & 2 & $0.87 \%$ \\
\hline
\end{tabular}

Source: own calculation. 
One of the explanations of the monthly effect occurrence may be publishing of significant macroeconomic information from global markets, as well as information regarding listed companies at the turn of the month. This type of view is expressed by Penman and Connolly (Penman, 1987) (Connolly, 1991). According to these two authors, the largest number of information concerning listed companies, appears just on weekends and at the turn of month. The similar conclusion are presented by Thaler, as well as Dyl and Maberly, who explain the existence of the-end-of-the-week effect and of the monthly effect as deposition of significant market information for the weekends and for the turn-of-the-month by listed companies (Thaler, 1987; Dyl \& Maberly, 1988).When analyzing the monthly returns, this explanation is far less important than the analysis of the weekend effect. The most reliable explanation of April effect, however, is a process of rebuilding investment portfolios by investors in those countries, in which fiscal year ends on March 31. Poorly performing shares are sold in March and investors buy back shares (frequently the same) in April, pushing up prices.

Foreign investor from counties, where other than calendar tax year inures, opening new long positions, contribute in this way to the creation of the April effect in selected countries.

Finally, it should be noted that the existence of positive returns on certain days of the week or months, and negative returns in others, is a characteristic feature of each of the financial markets and reflects the inefficiency of such a market. This type of approach can be found in French's work, who does not specify the causes of negative returns in the US market, considering them to be characteristic for the American market and providing for its inefficiency (French, 1980, pp. 55-69). A similar thesis was presented by Rogalski (Rogalski, 1984, pp. 835-837).

\section{Conclusions}

Assuming the acquisition of an index replicating portfolio on the last session in March and liquidating this positon on the last session in April (in both cases at close prices), calculations conducted in this paper proved the existence of returns statistically different from zero for the following stock market indices: All-Ord, AMEX, BUX, CAC40, DAX, DJIA, DJTA, DJUA, EOE, FTSE100, SMI, SP500. Returns statistically equal to zero were observed for the following indices: B-Share, Bovespa, Buenos, HangSeng, MEX-IPC, Nasdaq, Nikkei, Russel, TSE and WIG. 
The obtained result proved the existence of April effect on financial markets, thus confirming previous conclusions achieved by other researchers (Rozeff \& Kinney, 1976, pp. 379-402; Corhay et al., 1988, pp. 120135; Clare et al., 1995, pp. 398-409; Gultekin \& Gultekin, 1983, pp. 469481; Bernstein, 1996, pp. 76-77). This remark concerns mainly the British market, represented in the survey by the FTSE100 index, for which the existence of April effect was proved. The same effect occurred in the analyzed period for such Anglo-Saxon exchanges as American (represented in the research by indices: AMEC, DJIA, DJTA and DJUA) and for Australian (All-Ord index), but the April effect was not found in the case of other Anglo-Saxon indices as: Nasdaq and Russell (both USA) and TSE (Canada).

Research regarding the capital market effectiveness should be continued in the future, and its outcome compared with results obtained by other researchers.

\section{References}

Ariel, R. (1987). A Monthly Effect in Stock Returns. Journal of Financial Economics, 17(1). DOI: http://dx.doi.org/10.1016/0304-405X(87)90066-3.

Ariel, R. (1990). High Stock Returns Before Holiday: Existence and Evidence on Possible Causes. Journal of Finance, 45(5). DOI: http://dx.doi.org/10.1111/ j.1540-6261.1990.tb03731.x.

Bernstein, J. (1996). Cykle gietdowe, Warszawa: WIG-Press.

Buczek, S. (2005). Efektywność informacyjna rynków akcji. Teoria a rzeczywistość. Warszawa: Szkoła Główna Handlowa w Warszawie.

Choudhry, T. (2001). Month of the Year Effect and January Effect in Pre-WWI Stock Returs: Evidence from Non-linear GARCH. International Journal of Finance \& Economics, 6.

Clare, A., Psaradakis, Z. \& Thomas, S. (1995). An Analysis of Seasonality in the UK Equity Market. Economic Journal, 429(105). DOI: http://dx.doi.org/ $\underline{10.2307 / 2235499 .}$.

Connolly, R. (1989). An Examination of the Robustness of the Weekend Effect. Journal of Financial and Quantitative Analysis, 24(2). DOI: http://dx.doi.org/10.2307/2330769.

Connolly, R. (1991). A Posterior Odds Analysis of the Weekend Effect. Journal of Econometrics, 49. DOI: http://dx.doi.org/10.1016/0304-4076(91)90010-B.

Corhay, A., Hawawini, G. \& Michel, P. (1988). Stock Market anomalies. Cambridge: Cambridge University Press.

Czekaj, J., Woś, M. \& Żarnowski J. (2001). Efektywność giełdowa rynku akcji w Polsce. Warszawa: Wydawnictwo Naukowe PWN.

Dyl, E., \& Maberly, D. (1989). A Possible Explanation of the Weekend Effect. Financial Analyst Journal, 44. DOI: http://dx.doi.org/10.2469/faj.v44.n3.83. 
Fama, E. (1970). Efficient Capital Markets; a Review of Theory and Empirical Work. Journal of Finance, 25(2). DOI: http://dx.doi.org/10.2307/2325486.

Fountas, S. \& Konstantinos, S. (2002). Emerging Stock Markets Return Seasonalities: the January Effect and the Tax-loss Selling Hypothesis. Applied Financial Economics, 12(4). DOI: http://dx.doi.org/10.1080/09603100010000839.

French, K. (1980). Stock Returns and Weekend Effect. Journal of Financial Economics, 8 (1). DOI: http://dx.doi.org/10.1016/0304-405X(80)90021-5.

$\mathrm{Gu}$, A. (2003). The Declining January Effect: Evidence From U.S. Equity Markets. Quarterly Review of Economics and Finance, 9(2). DOI: http://dx.doi.org/10. 1016/S1062-9769(02)00160-6.

Gultekin, M. \& Gultekin, B. (1983). Stock market seasonality: international evidence. Journal of Finance, 12.

Hasan, T. \& Raj, M. (2001). An Examination of the Tax Loss Selling Behavior in a de-regulated Pacific Financial Market. American Business Review, 19.

Hirsch, Y. (1987). Don't Sell Stock on Monday. New York: Penguin Books.

Jaffie, J., Westerfield, R. \& Ma, C. (1989). A Twist on Monday Effect in Stock Prices: Evidence from the US and Foreign Stock Markets. Journal of Banking and Finance, 13(4-5). DOI: http://dx.doi.org/10.1016/0378-4266(89)90035-6.

Jajuga, K. \& Jajuga, T. (2006). Inwestycje. Warszawa: Wydawnictwo Naukowe PWN.

Kato, K., Schwarz, S. \& Ziemba, W. (1990). Day of the Weekend Effects in Japanese Stocks, Japanese Capital Markets. New York: Ballinger.

Keim, D. (1983). Size-related Anomalies and Stock Return Seasonality: Further Empirical Evidence. Journal of Financial Economics, 12(1). DOI: http://dx.doi.org/10.1016/0304-405X(83)90025-9.

Kim, C. \& Park, J.(1994). Holiday Effects and Stock Returns: Further Evidence. Journal of Financial and Quantitative Analysis, 29(1). DOI: http://dx.doi.org/10.2307/2331196.

Lakonishok, J. \& Maberly, E. (1990). The Weekend Effect: Trading Patterns of Individual and Institutional Investors. Journal of Finance, 45(1). DOI: http://dx.doi.org/10.2307/2328818.

Lakonishok, J. \& Smidt, S. (1988). Are Seasonal Anomalies Real?. Journal of Financial Economics, 13. DOI: http://dx.doi.org/10.1016/0304-405X(84) 90008-4.

Li, B. \& Liu, B. (2010). Monthly Seasonality in the New Zealand Stock Market. International Journal of Business, Management and Economic Research, 1(1).

Nowakowski, J. \& Borowski, K. (2005). Zastosowanie teorii Carolana i Fischera na rynku kapitatowym. Warszawa: Difin, Warszawa.

Penman, S. (1987). The Distribution of Earnings News over Time and Seasonalities in Aggregate Stock Returns. Journal of Financial Economics, 18. DOI: http://dx.doi.org/10.1016/0304-405X(87)90039-0.

Raj, M. \& Kumari, D. (2006). Day-of-the-week and Other Market Anomalies in the Indian Stock Market. International Journal of Emerging Markets, 1(3). DOI: http://dx.doi.org/10.1108/17468800610674462. 
Raj, M. \& Thurston, D. (1994). January or April? Test of the Turn-of-the-yeareffect in the New Zealand Stock Market. Applied Economics Letters, 1(5). DOI: http://dx.doi.org/10.1080/135048594358195.

Reinganum, M. \& Shapiro, A. (1987). Taxes and Stock Return Seasonality: Evidence from the London Stock Exchange. Journal of Business, 60(2). DOI: http://dx.doi.org/10.1086/296396.

Rogalski, M. (1984). Discussion to Keim and Stambaugh. Journal of Finance, 3.

Rozeff, M. \& Kinney, W. (1976). Capital Market Seasonality: the Case of Stock Returns. Journal of Financial Economics, 3(4). DOI: http://dx.doi.org/10.1016/ 0304-405X(76)90028-3.

Simson, E. (1988). Stock Market Anomalies. Cambridge: Cambridge University Press.

Schwert, W. (2002). Anomalies and Market Efficiency. Simon School of Business Working Paper, FR 02-13. DOI: http://dx.doi.org/ 10.2139/ssrn.338080.

Szyszka, A. (2007). Wycena papierów wartościowych na rynku kapitałowym $w$ świetle finansów behawioralnych. Poznań: Wydawnictwo Akademii Ekonomicznej w Poznaniu.

Thaler, R. (1987). Seasonal Movements in Security Prices II: Weekend, Holiday, Turn of the Month and Intraday Effects. Journal of Economic Perspectives, 1. DOI: http://dx.doi.org/10.1257/jep.1.2.169. 